なり。

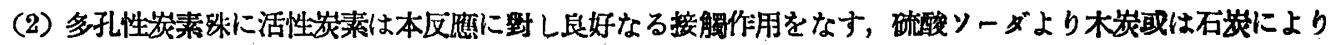
還元せる焦の過剩炭素を含む硫化ンーがは恐らく同㧺の理由により甚だ容易に分解せらる。

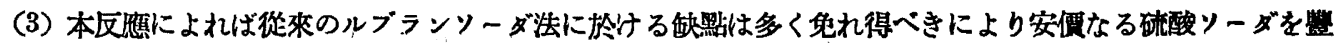
富に供給せらる〉場合にはその操作の簢單なる理由によりて工業化の可能性充分存すべきすのと信ず。

（柬京工業㽞驗所第 6 部研究室）

\title{
シアナミトの罨壁滴定法に就て 篠崎平馬
}

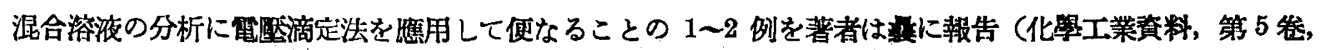
第4 號) せるが， $\mathrm{NaCN}$ と $\mathrm{Na}_{2} \mathrm{CN}_{2}$ の混合溶液に就てす電因滴定法が甚だ適當なることを知り，更に之を石 灰等素に應用せしに不純物たる硫化物に對する補正を必要とすれども，䗰用に供し得べきことを知りたるを以 てここに報告せむとす。

本虫驗に使用せる試料はカールバウム社製 $\mathrm{Na}_{2} \mathrm{CN}_{2}$ 及び肥料用石灰空素 2 種なり。解滴定裝置は化學工 策資料に記戴せる如し。滴定液としては $\mathrm{N} / 10 \cdot \mathrm{AgNO}_{3}$ を用ひたり。

\section{(1) $\mathrm{Na}_{2} \mathrm{CN}_{2}$ の 分析}

$\mathrm{Na}_{2} \mathrm{CN}_{2}$ に就き純粹にて又は $\mathrm{NaOH}, \mathrm{NaCN}$ 等を混じて滴定せる結果を第 1 表に示す。其滴定曲線は何れ も明かなる㭧變點を示す。その例として $\mathrm{Na}_{2} \mathrm{CN}_{2} に \mathrm{NaOH}$ を混じたる場合 (第 1 圆) $\mathrm{NaCN}$ を混じたる場

第 1 图

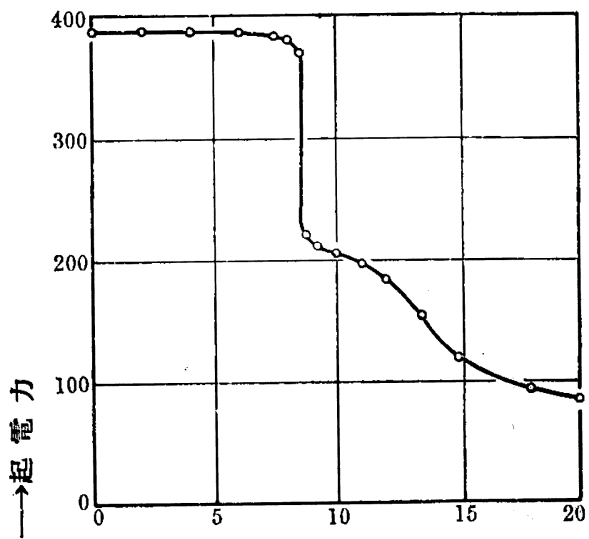

一 $\rightarrow$ 确酸銀 cc

料部算值 $\mathrm{cc}$

$\mathrm{Na}_{2} \mathrm{CN}_{2}$

$\mathrm{Na}_{2} \mathrm{CN}_{2}$

$\left\{\mathrm{Na}_{2} \mathrm{CN}_{2}\right.$

NaCN

$\mathrm{Na}_{2} \mathrm{ON}_{2}$

NaCN
(8.88)

8.88

8.88

8.56

8.88

8.56
第 1 表

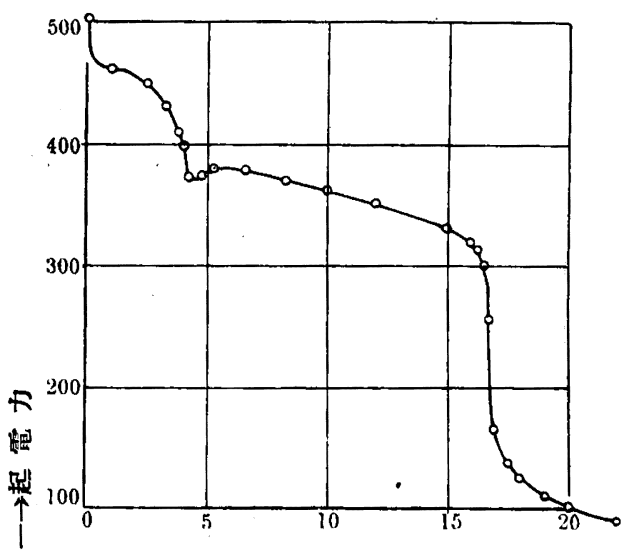

一硝酸銀 cc

宽瞼值 $\mathrm{cc}$ 8.88 8.88

8.67

8.67

8.67

8.67
誤 虐 cc

0.0

$-0.21$

$+0.11$

$-0.21$

$+0.11$
添 加物

$N / 10 \mathrm{NaOH} 5 \mathrm{cc}$

$N / 10 \mathrm{NaOH} 5 \mathrm{cc}$ 
合 (第 2 圆) を示す。郎ち $\mathrm{Na}_{2} \mathrm{CN}_{2}$ の硝酸銀による電壓滴定は甚だ明嘹なる終點を示すのみならず, $\mathrm{NaOH}$ 又は $\mathrm{NaCN}$.の存在に於てる略了滴定誤差以內に於て定量し得ることを知れり（元來本䨳驗の動機は他の研究 の必要上 $\mathrm{NaCN}$ と. $\mathrm{Na}_{2} \mathrm{CN}_{2}$ との混合物の简便なる定量法を求むるにありたり)。

第 2 表には電国滴定法と他の 2 方法, 郎ちヶールダール法及デバルダ法との比较を示せり。

\begin{tabular}{|c|c|c|c|c|c|}
\hline 試料番號 & $\begin{array}{l}\text { 試娬溶液 } \\
\text { 探取 }\end{array}$ & 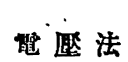 & ケールダール法 & デバルダ法 & 備 \\
\hline $\mathbf{A}$ & 10.00 & 8.88 & 8.45 & 8.66 & 溶解後数日内 \\
\hline $\mathbf{A}^{\prime}$ & 25.00 & 21.14 & 21.52 & 21.47 & 粎 20 日耙過後 \\
\hline B & 25.00 & 21.05 & 20.58 & 20.37 & 試料溶解當日 \\
\hline $\mathbf{B}^{\prime}$ & 25.00 & 20.64 & & & 溶解 後 6 日目 \\
\hline
\end{tabular}

試料 A 及 B は同一固熋試料を時を異にして溶解し溶解當日乃至一兩日中に分析せるすのにして $\mathrm{A}^{\prime}$ の結 果は $\mathrm{A}$ を約 20 日經過後 $\mathrm{B}^{\prime}$ は B を 6 日後分析せるものなり。之により斌料溶液調製直後に於ては電痴法 は他の 2 法に比しや小大なる值を與ふるる時日經過後に於てはその逆なるを知る。之れ $\mathrm{Na}_{2} \mathrm{CN}_{2}$ が溶液中に 於て加水分解を受くるによるものなり。而して溶解直後に於て電原法の方や」大なるは他の 2 法に於ける $\mathrm{NH}_{3}$ への分解が不充分なるによるものにしてこの場合他に $\mathrm{Ag}$ に作用するすのなく且同一特に行ひたる數间の結 果がよく一致する故電盐法の結果が正しきすのと思惟す。デバルダ法郎ちアルカリ性溶夜に於てデバルダ合金 により $\mathrm{NH}_{3}$ に還元する方法か不㴖足なる結果を與ふることは後述の $\mathrm{CaCN}_{2}$ の場合には更に著し。 $\mathrm{Na}_{2} \mathrm{ON}_{2}$ の䭪合はヶールダール法と大差なき程度なり。

\section{(2) 石 灰鯑素 $\oslash$ 分 析}

以上の結果により $\mathrm{Na}_{2} \mathrm{CN}_{2}$ の分析に $\mathrm{AgNO}_{3}$ を用ふる電䢔滴定法の適當なることを知りたるが故に, 次に 之を肥料用石灰呿素に㕍用の可否に就き检せり。其結果を第 3 表に示す。此場合の滴定曲線も亦 $\mathrm{Na}_{2} \mathrm{CN}_{2}$ 同 㨾明かなる急變熙を示す，例として中性抽出液及び醋酸々性抽出液に就ての結果を第 3 圖及第 4 圖に示せ

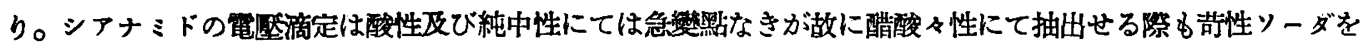

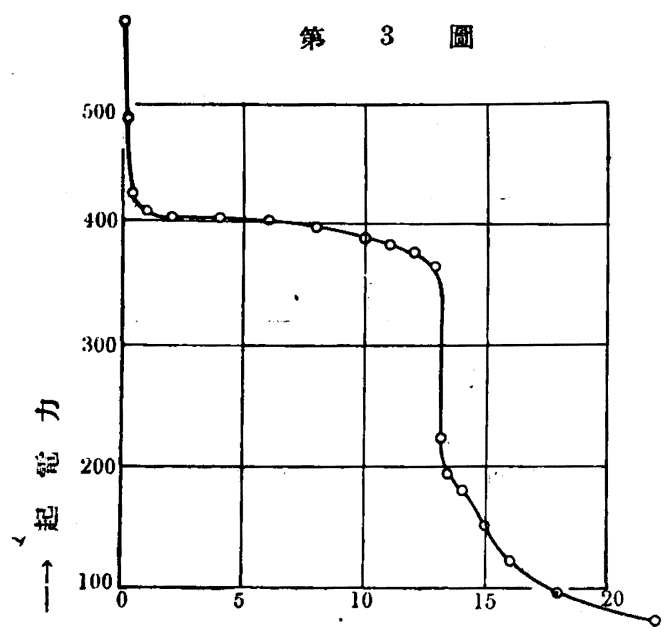

$\longrightarrow$ 硝 酸 銀 cc

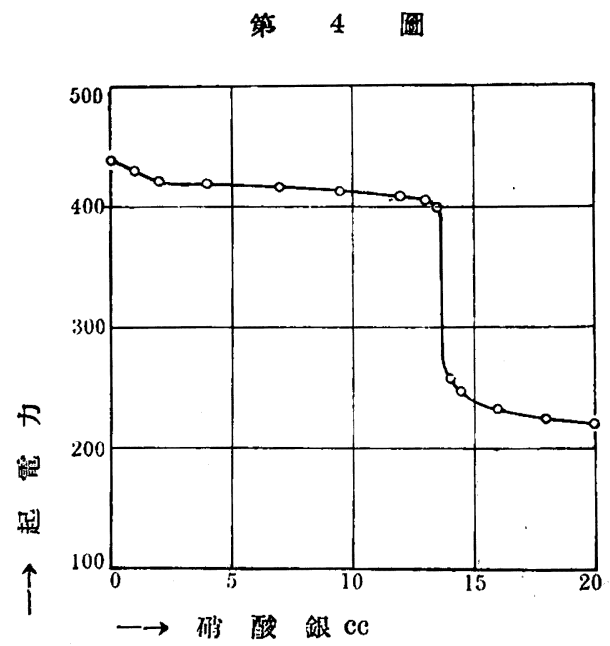


加へてアルカリ性にせる後滴定せり。符 3 圖に於て滴定の始に著しき電壓の變化を示せるは試料中に存在せる

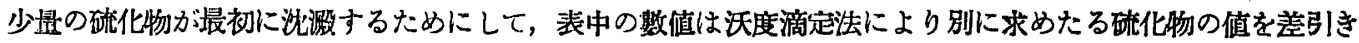
たるるのなり。

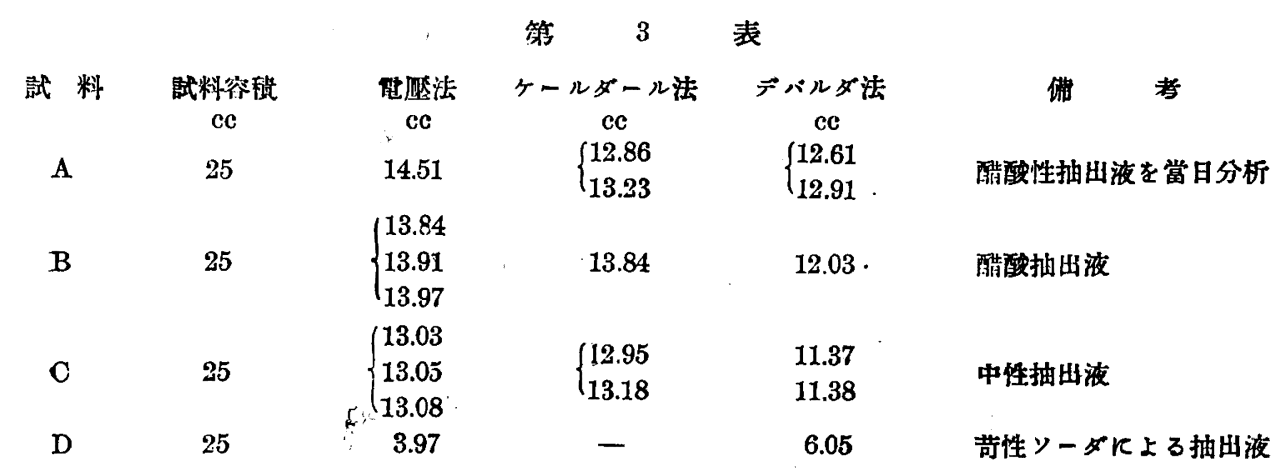

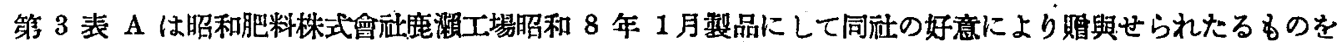
直に分析せり。又 $\mathrm{B} ＼textrm{C}$ 及 $\mathrm{D}$ は何れる電氣化學工業株式會社大龺田工場にて大正 14 年 9 月製造せるるのに して幾分分解し居れり。 B， C 及 D は表示の如く瞥酸々性，中性及アルカリ性にて他は同一條件にて抽出せる るのなり。中性及アルカリ性にては抽出不完全なる故醌酸々性にて抽出するを可とす。酸性にては硫化物が大 部分分解して溶液中に有寸る量は甚だ少くこの點よりも好都合なり。又表中にヶールダール法及デバルダ法に よる結果も比較のため示せり。元來ヶールダール法は多くの窒素化合物に適用し得る利照あるる操作の途中失

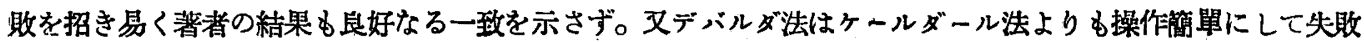
の機會少く著者は管て硝酸の定量に用ひて甚だ好都合なりし經驗により試みたるす Lunge 著 (Technical Method of Ohem. Analysis, III, 507)にも記载しある如く石灰空素に黕しては分解は約 80〜90\%に停止す。 東京工業試驗所西村笁吉氏の經驗によればデバルダ法にて石灰䇪素中の全䇪素を定量する場合, 大部分が $\mathrm{NH}_{3}$

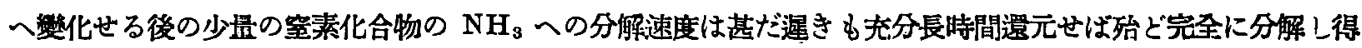
ることを認められ居れり (未發表)。

\section{結 論}

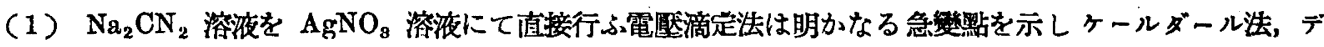
バルダ法よりも簡便にして正確なる值を得らるよことを示せり。 $\mathrm{NaOH}$ の影響なく $\mathrm{NaCN}$ と共存する時その 兩者を 1 夘の滴定にて求め得。

（2）石灰空素中のシアナミドの定量にも不純物たる硫化物に對し補正を施せば正踓なる值を得たり。

（3）デバルダ法は $\mathrm{Na}_{2} \mathrm{CN}_{2}$ に就ては大部分 $\mathrm{NH}_{3}$ へ還元し得べきす; 石灰窒素の場合は短時間の還元に ては約 $90 \%$ に止まり䖵用的ならず。

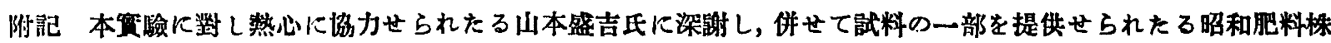

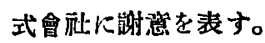

